ISSN: 2162-3104 Print/ ISSN: 2166-3750 Online Volume 9, Issue 1 (2019), pp. 150-171

(C) Journal of International Students ojed.org/jis

\title{
Helping International Master's Students Navigate Dissertation Supervision: Research-Informed Discussion and Awareness-Raising Activities
}

\author{
Nigel Harwood \\ University of Sheffield, UK \\ Bojana Petrić \\ Birkbeck College, University of London, UK
}

\begin{abstract}
Drawing on a longitudinal case study of supervisees' and supervisors' experiences of master's dissertation supervision in a U.K. university, we identify prominent themes and use excerpts from our data to design pedagogic activities to use in workshops with staff and students focused on supervisory practice. The activities ask workshop attendees to consider experiential supervisory narratives involving students' social networks, problems interpreting supervisors' feedback, problems with differing supervisorsupervisee role expectations, and problems with supervisor-supervisee miscommunication. Each scenario is followed by our literature-informed commentary. We argue that these empirically informed, grounded awarenessraising activities will alert supervisors and supervisees to common problems experienced during supervisory journeys, and will encourage them to consider their own supervisory expectations and practices more deeply.
\end{abstract}

Keywords: dissertation writing, higher education, supervision, supervisor development, support, thesis writing, tutoring 


\section{INTRODUCTION}

This pedagogically focused article draws upon the results of a year-long study in which we examined how international students and their supervisors experienced master's dissertation supervision (Harwood \& Petrić, 2017), defining international students as students "who have crossed borders for the purpose of study" (Organization for Economic Cooperation and Development, 2013). The students were from various humanities and social sciences disciplines and were studying in a research-intensive U.K. university. We took a longitudinal case study approach (e.g., Duff, 2008), in which five supervisory journeys were charted from beginning to end, drawing upon a range of methods and data sources, including student and supervisor interviews, diaries, supervisee draft chapters, supervisors' feedback on these chapters, and analysis of examiners' final assessments of the dissertations. We also consulted departmental supervisory guidelines, regulations, and assessment criteria. During the supervision, we looked at what happened and why; and how each party, supervisor and supervisee, felt about and evaluated the supervision. During the initial stages of their journey, some students were struggling to draft an initial dissertation proposal and sought the help of various parties to drive their projects forward; while early on in the supervision, supervisors were explaining supervisory arrangements, such as the expectations they had of their supervisees and the extent to which they would comment on draft chapters. As the journeys progressed, we continued to chart their peaks and troughs, as well as analyzing supervisees' writing and supervisors' feedback, both oral and written, on their supervisees' work. Towards the end of the dissertation experience, we asked both parties to reflect upon various pedagogic models of supervision from the literature, seeking to determine the extent to which the pedagogy enacted by the supervisor and experienced by the supervisee aligned with one or more of the models. We also solicited informants' preferred pedagogies and their recommendations for how to enhance the supervision experience for both parties.

Summarizing our results, we noted that our findings were "uplifting, depressing — even shocking" (Harwood \& Petrić, 2017, p. 1). This was because of the varied experiences and practices of the supervisees and supervisors we spoke to and heard about. Some supervisees described transformative experiences, such as the dissertation being a period during which their disciplinary and academic literacy knowledge dramatically increased. They spoke of their thankfulness for supervisors who went above and beyond their call of duty in helping effect these transformations. For other students, though, the dissertation experience was less happy: some spoke of what can only be seen as negligent supervisory practices, during which their requests for meetings were ignored and their pleas for feedback unanswered. 
We conducted this research for a number of reasons, one being that master's supervision is far less researched than doctoral supervision; another being because we wished to better understand and describe the various roles enacted by supervisor and supervisee at different stages of the supervisory journey. However, one of the strongest drivers behind the project was pedagogic. We were aware that the literature suggests that both supervisees and supervisors can be unsure as to the roles required of them and how far they are permitted to ask for or provide help, as Grant (2010a), Todd, Smith, and Bannister (2006), and Turner (2015) make clear. We also knew from our own experiences of supervising students over the years that colleagues within and across departments have different ideas about their responsibilities and the amount of time they should spend supervising. Then there is the fact that the literature suggests that unhappy supervisory experiences are not uncommon (cf. Acker, Hill, \& Black, 1994; Aspland, 1999; Delamont, Atkinson, \& Parry, 2000; Grant \& Graham, 1994; Green, 2005; Guerin, Kerr, \& Green, 2015; Krase, 2007; Manathunga, 2014; McAlpine, Paulson, Gonsalves, \& JazvacMartek, 2012, to cite merely a selection of sources describing such experiences). These unhappy dissertation journeys are sometimes caused by supervisor-supervisee miscommunication (e.g., Blakeslee, 1997; Krase, 2007; Schneider \& Fujishima, 1995; Vehviläinen, 2009), and we felt learning more about such experiences would help us better understand this phenomenon and its causes.

Many of these accounts involve international students whose first language is a language other than English, and as educators with interests in the teaching of English to speakers of other languages, our research focused exclusively on this international student population. We go on to identify our international students experiencing difficulties related to social networks, problems interpreting supervisors' feedback, and with role expectations of themselves and of their supervisors with which the latter may not agreethemes to which we anticipate our readers who also work with international students will easily relate. This is not to say that we feel our findings are only relevant to students who are international students; indeed, we are of the view that many of the troubling attitudes, beliefs, and practices we uncovered could equally apply to the supervision of home students. Nonetheless, our work expands upon and enhances the work done on international student supervision and adopts a highly practical bent. Furthermore, given that international student numbers continue their inexorable rise (Manathunga, 2014; UNESCO, 2016), such work is particularly timely. As a result of conducting research into supervision, then, we would be in a more informed position to share our findings with teaching and learning units and committees responsible for scheduling supervisor training or drawing up supervisory policies for staff and students, and our research could help our colleagues formulate guidelines 
designed to combat these dangers and difficulties. We envisaged being able to offer something currently lacking in the literature: grounded supervisory episodes and narratives that can serve as awareness-raising pedagogic activities for staff and students with reference to supervision and supervisory practices. Hence, this paper enables us to bridge a gap between research and practice: between researching supervision and offering materials for supervisees and supervisors that encourage reflection upon supervision. We also note that while many universities offer students support courses dealing with writing and other more generic management skills (e.g., help with time management), there is far less commonly sustained preparation for supervision, which is an occluded practice (Grant, 2008; Lee, 2008) and as such is unfamiliar to many students, a large number of whom have never previously experienced it. Rather, it seems there is an assumption that reading departmental guidelines about what supervision entails (e.g., in terms of rights and responsibilities, the number of supervisory meetings permitted, etc.) will be enough to enable students and lecturers to competently perform the role of supervisee or supervisor. As we shall see, however, our research painted a different picture, and we therefore argue that our awareness-raising activities will enable students and staff to reflect upon their roles more deeply.

Hence, below we outline some of the prominent issues that emerged from the research and pedagogic activities we propose to enable students and supervisors to engage with these issues, by reflecting upon their own supervisory beliefs and practices. Indeed, we have used these activities in workshops for supervisors working with both master's and doctoral students, learning and teaching colleagues, and English for Academic Purposes tutors in U.K. universities, where they have generated a good deal of debate and reflection.

\section{PREVALENT THEMES}

\section{Helpful and Unhelpful Social Networks}

During the course of their studies, supervisees consulted circles of family, friends, acquaintances, and academics when they encountered difficulties, with varying degrees of effectiveness. As Zappa-Hollman (2007) has shown (also Zappa-Hollman \& Duff, 2015), these networks can help smooth the path for students' disciplinary and institutional enculturation, and supervisees, support tutors, and teaching and learning professionals would do well to consider who may be best placed to advise when students experience various kinds of difficulties.

Several of the supervisees in our research experienced problems related to their research methodology, and in the episode we describe below, the supervisee Jay (all names are pseudonyms) eventually turned to his social 
network for help. Jay spoke of how, despite the fact his department provided an obligatory research methods module that was supposed to equip students to understand and account for the methodological choices they would make in their dissertation, he struggled to understand the concepts of epistemology and ontology. To make matters worse, he claimed the readings provided by the module lecturer (who was also his supervisor, Billy) were too difficult for him to grasp: Indeed, he said the more he read about epistemology and ontology, the more confused he became. In our worksheet describing this scenario (Scenario 1), we invite discussion of possible ways to resolve this problem, as well as providing a possible solution for evaluation. (All scenarios taken from Harwood \& Petrić, 2017; permissions granted.)

Scenario 1: Problems related to research methodology
"The more I read, the more confused I become"
Jay: Supervisee
Billy: Supervisor
Jay's department provided an obligatory research methods module that was
supposed to help him to understand and account for the methodological
choices in their dissertation. But he struggled to understand the concepts of
epistemology and ontology. This module was taught by Billy, who was also
Jay's supervisor. Jay claimed the readings provided by Billy during the
module were too difficult for him to grasp: Indeed, he said the more he read
about epistemology and ontology, the more confused he became.
What should Jay do to solve this problem?
possible solutions that come to mind?
What are some of the potential dangers or difficulties with each of the
One possibility would be for Jay to seek advice on reading from friends on
master's programmes at other universities. How do you feel about this
idea?
What, on balance, seems to be the best option? Why?

Obviously there are issues of trust and face here. If the research methods module convenor had been someone else other than his supervisor, it would likely have been less face-threatening for Jay to solicit advice from Billy about more basic, introductory readings. However, Jay may have felt that, having tried and failed to understand the readings Billy had suggested, he needed to seek help elsewhere. The way Jay in fact resolved the problem was by asking friends in master's programmes in different departments and at different 
universities for advice on "easier" readings that he found "more direct," "more to the point."

Despite Jay's network supplying alternative readings, it turned out that when Billy read Jay's draft methods chapter, there were still problems with his use and understanding of the terms epistemology and ontology. While supervisees' social networks can of course play an important role in helping students gain disciplinary knowledge and provide emotional support (Kuwahara, 2008; Liu et al., 2008; Seloni, 2012; Taha \& Cox, 2016), they may not always be so beneficial. In Krase's (2007) case study of a problematic supervisory experience, the Korean master's student in focus lacked a social network at her U.S. university, and so consulted family and friends when she experienced difficulties with her research. However, the advice she received led her to take unwise methodological decisions, as her advice-givers were unfamiliar with her programme and its demands. In Jay's case, the extent to which the suggested reference works were good choices is open to question; but the fact remains that, despite reading these supposedly "easier," "more direct" sources, he was still unable to demonstrate an adequate level of understanding in his writing. This scenario opens up the possibility, then, of the discussion of the potential benefits and dangers of supervisees seeking to resolve their problems using sources other than the supervisor. Other (possibly more helpful) sources could have included different lecturers in the department, or PhD students - or indeed Jay's supervisor Billy, with Jay confessing that he was experiencing difficulty with Billy's suggested readings.

Another of our supervisees, Clara, successfully called upon a disciplinary insider other than her supervisor, visiting a lecturer she had had no contact with to solicit help with her literature search. (Clara had read one of this lecturer's recent articles and correctly believed she would possess the necessary knowledge to help.) Laura, another of our supervisees, was required to shoot a film as part of her non-traditional dissertation (see Paltridge, 2004; Starfield \& Ravelli, 2006 for more on non-traditional dissertations), and sought the help of friends who possessed a greater degree of technical know-how to do so, with a certain amount of success. But in another of our cases, Janet's supervisor could only be described as negligent, and unfortunately Janet's network provided similarly inadequate support. Her network can be divided into two parts: (a) students from her own peer group, who were struggling as much as she was and were unable to answer her questions about methodology with authority; and (b) former workplace colleagues located in her home country, who again seemed to us not to be able to provide helpful advice, probably because they were unfamiliar with the academic requirements being made of Janet. Hence, like the other scenarios we present below, we are not claiming there is a pat answer workshop participants of these activities should be offering. Social networks no doubt have their uses, but, as Zappa-Hollman (2007) showed, they can vary in 
their helpfulness depending on their composition, and depending upon the advice being sought. In this case, if supervisees are considering the scenario, they can perhaps be alerted to alternative sources of advice they may not have considered they could consult, and if the workshop participants are supervisors, they may consider whether and to what extent supervisees should be provided with introductory readings to allow students like Jay to begin to get to grips with key concepts. More generally and more closely related to the social network theme, supervisors may also go on to discuss common problems and questions supervisees have and who should answer them.

\section{Problems Interpreting Supervisors' Feedback}

Throughout her time as a master's student, Laura struggled to "read" or decode her lecturers' feedback. She was accustomed to a much more direct, critical style of commentary she received from lecturers in her home country, and had difficulties understanding why, for her U.K. work, she received poor grades when the marker had found things to praise. Scenario 2 below is designed to get workshop participants to consider how supervisees like Laura can become more skilled in getting to the nub of the messages their supervisor is intent on conveying.

\section{Scenario 2: Problems with the master's dissertation proposal "If I have all these good things, don't they count for anything?"}

\section{Laura: Supervisee}

\section{Rosie: Supervisor/Marker of Laura's dissertation proposal}

\section{Laura is doing a "non-traditional" dissertation, consisting of making a} film and an accompanying text about her film.

Laura had to develop a dissertation plan, including a bibliography of 20 works. For 10 of these references, Laura needed to write a commentary about their relevance to her dissertation. Laura was proud of her paper, expecting to receive a high mark (65). But to her great disappointment, she was awarded a mark of 58 .

Laura's paper mostly focused on details of the film she was planning to make (what would be filmed, from what angles, with what cameras) but offered little in the way of explanation of her motivation for the project or reference to theoretical concepts or other literature. The annotations presented a mix of a summary and statement of importance to the project. Most were rather general and vague, as in the following typical example: 


\begin{tabular}{|l|l|}
\hline I believe this book will help me with the \\
[author] makes a thorough analysis of [name of \\
film] from most points of view. Several topics \\
raised in this book are of interest to me, such \\
as: [list of topics]. \\
I have chosen this book because I believe it to \\
be most helpful with my understanding of [film \\
influencing Laura's project] from so many \\
perspectives, and thus finding my own \\
explanations for it. Moreover, when put next to \\
[book title] another book I will use for this \\
project, that contains the director's own \\
writings explaining how he came to do this film, \\
how he envisioned it and even why he gave it \\
this name, I think I have an almost complete \\
support for understanding the film and its \\
implications. By understanding [film influencing \\
Laura's project] I will be able to comment on \\
it, to criticise it and to draw conclusions.
\end{tabular}

Rosie's feedback on Laura's dissertation plan started by an encouraging positive comment on the overall idea but went on to highlight a number of problems, the most important of which was that the plan "does not delve into the material with sufficient detail and depth":

The dissertation plan includes a strong outline describing what
promises to be a very interesting field project both in terms of
the themes it addresses and its stylistic format. The choice of
[name of film] as a key stylistic influence helps to consolidate
the social historical document side of your project. Your
annotated bibliography gives evidence of some critical reading
in relation to your chosen themes identifying some key sources.
But although it covers major points, it does not delve into the
material with sufficient detail and depth. The bibliography is
also not entirely properly presented. Please consult the MA
booklet for guidelines and ensure that you proofread your work
carefully as the typographical errors proliferate over the last few
pages.

Clearly disappointed, Laura's first reaction in the interview, which took place shortly after she received the mark, was defensive, focusing on 
typographical errors, such as the misspelt names of authors in the bibliography:

These are mistakes that the computer makes. I correct them and then the computer goes back and does it again.

She was also annoyed by what she perceived as a discrepancy between the amount of criticism in the overall feedback and the mark:

This entire part, three quarters, is good, and then for two lines, two three mistakes, you give me a 58. And don't point out the good things if you're going to give me such a small mark, because then the question is if I have all these good things, don't they count for anything? I mean, you only said this is bad. I'm going to have ten points taken out because this one thing is bad, and another ten points because this thing is bad, and then you go 58. And where do the good parts come in?

What are the lessons to be taken from this episode?

How could this episode be used by lecturers or support tutors to help students?

An immediate issue here is to familiarize the supervisee with the feedback genre (in the West, at least, if not in universities in Laura's own country). She needs to become familiar with the "good news-bad news" form of feedback often found in lecturers' comments that Hyland and Hyland (2001) call pairedact patterns, something we believe lecturers or support tutors could help students to understand. In their study of feedback by English language teachers given to international students on their writing at a New Zealand university, Hyland and Hyland (see also Hyland, 1998) found that markers would often use indirect language (such as hedges or questions) or ensure negative comments were combined with positive ones ("Good ideas, but...") to try to make their criticisms less harsh and to maintain good relations with the recipient. However, students at times struggled to understand the essence of the less direct messages. Similarly, in Scenario 2, Laura struggles to understand what she has done wrong, since the most important part of the feedback ("But 
although it covers major points, it does not delve into the material with sufficient detail and depth") is preceded by positive comments about less important matters. Laura also assumes that the space Rosie devotes to each point should reflect its importance ("This entire part, three quarters, is good, and then for two lines, two three mistakes, you give me a 58"). Readers may feel that Laura has a point - in which case, the scenario can be used by teaching and learning staff to have lecturers reflect on their feedback practices - but it is no doubt the case that many lecturers will not devote as much space to explaining the key parts of their feedback as they could and maybe should, and so supervisors need to learn to attempt not only to make their feedback as explicit as they can, but also to check, perhaps in a follow-up supervisory meeting, that supervisees have grasped the key messages being transmitted.

\section{Problems with Differing Supervisor/Supervisee Role Expectations}

If they have previous experience of supervision, supervisees (and supervisors) bring to the supervision their supervisory history, the manner in which they have been accustomed to receive or give supervision. Clara had written an undergraduate dissertation in her home country, but had enjoyed a very different type of supervisory relationship with her supervisor there. Clara described how her undergraduate supervisor provided very clear deadlines and stage-by-stage guidance she was expecting to also be given by her U.K. master's supervisor - but encountered a very different type of supervisory pedagogy.

\section{Scenario 3: Differing supervisory preferences: Laissez-faire vs. directive "Here it's just like 'It's up to you'."}

\section{Clara: Supervisee}

Clara was used to a fairly directive, top-down supervision style from her undergraduate dissertation. She explained how she had been given regular deadlines for tasks, and appreciated this way of doing things. However, her master's supervisor was much more hands-off:

Clara: I like to have deadlines but he's not really saying "Ok, give me this." It depends on me $100 \%$.

Int: He leaves that to you.

Clara: Yes, totally. Yeah, so, I'm used to deadlines so-

Int: That's what you've had in the past?

Clara: Yes. In [home country]. 


\section{Int: Your professor told you when you had to do things? Clara: Yes, exactly. But here it's just like, 'It's up to you.'}

And so while her supervisor would provide rough suggestions on how long Clara would probably need to write a literature review, collect and analyze the data, and to write up the dissertation, he didn't give Clara a series of dates by which she had to get them done or show him; and while he would suggest references to consult and analytical models she could use in her research, the onus was on Clara rather than her supervisor to shape the project.

What are the lessons to be taken from this episode?

How could this episode be used by lecturers or support tutors to help students?

Clara experienced a supervisory style during her undergraduate dissertation reminiscent of Dysthe's (2002) teaching model, while her master's supervisor appears to adopt a model more reminiscent of Gatfield's (2005) laissez-faire approach. Dysthe (2002), Gatfield (2005), and others (e.g., Brown \& Atkins, 1988; Hockey, 1994, 1997; Lee, 2008, 2012; Salmon, 1992; Vilkinas, 2005) reveal the diverse range of supervisory styles open to supervisors and the difference in practices adopted from discipline to discipline (cf. Acker et al, 1994; Delamont et al., 2000; Golde, 2010; Halse, 2011) and even within the same discipline (Burns, Lamm, \& Lewis, 1999). However, the literature also tells us that the supervisee and supervisor may have very different conceptualizations of their roles. In Aspland's (1999) and Krase's (2007) case studies, for instance, the focal international students both expected their supervisors to be much more directive, helping them at every turn. Similarly, Janet, our student who received very little supervision, expected the same and was very upset when her expectations were not met.

Intriguingly, another of our supervisees, Victoria, began her supervisory journey hoping for the same supervisory pedagogy as the international students in Aspland's (1999) and Krase's (2007) studies, and Janet in our study ("I've not done this before, I want to be told exactly what to do"; Harwood \& Petrić, 2017, p.71), but over the course of the dissertation came to appreciate her supervisor's later slackening of the reins to enable her to put her own stamp on her project. And so Victoria's preferred supervisory pedagogy comes to align with the enacted pedagogy of her supervisor. But in the case of Aspland's and Krase's supervisees, no such alignment ever takes place. Scenario 3 doesn't tell us whether accommodation is ever reached, but it requires workshop participants to consider the extent to which supervisory pedagogies can and should be negotiated: Should Clara simply accept her 
supervisor's enactment of supervision, or should she try to question and challenge him? After all, the literature also reveals that many supervisors enact what de Kleijn and colleagues (de Kleijn, Bronkhorst, Meijer, Pilot, \& Brekelmans, 2016; de Kleijn, Meijer, Brekelmans, \& Pilot, 2015) call "adaptive" supervisory pedagogy, varying their style and degree of directiveness from student to student and during the course of a supervision (see also Grant, 2010b; Hockey, 1996; and Lee, 2012 on supervisors' ability to "improvise" and to be "flexible"). If a supervisee makes clear s/he wishes the supervisor to enact a different form of pedagogy, an adaptive supervisor may well grant this wish - or at least go some way towards accommodating it. Clara reportedly enjoyed a good relationship with her supervisor, but never in fact requested a change of supervisory arrangements. Should she have done so? Should lecturers and support tutors encourage students like Clara to make such requests? If so, how? Or should students be encouraged to embrace a different style of work to the one they are used to, trusting the supervisor's assessment of their actual needs? Workshop participants here have much to ponder as they seek ways in which Clara's needs could be addressed.

\section{Problems with Supervisor-Supervisee Miscommunication}

All of our cases, even those involving engaged, motivated, highly capable students and diligent, assiduous supervisors, were tainted with miscommunication of some kind. For instance, Clara and her supervisor miscommunicated about the approach to data analysis she would take, the miscommunication only surfacing 2 weeks before the dissertation submission deadline. Consequently, Clara's supervisor asked her to make major changes to her draft analysis in a short space of time as he was unhappy with her approach. In the Victoria/Harriet case, Victoria worked diligently on her dissertation throughout, and relations with her supervisor were very amicable. Yet again there was miscommunication that nearly had serious consequences. Victoria was unaware that in her discipline and her research paradigm, it is essential for readers to be given enough detail of methodological procedures to be able to replicate the study. Harriet assumed Victoria would be aware of this disciplinary/paradigmatic convention, but that wasn't the case - and so here the lack of communication led to important misunderstandings on Victoria's part and nearly cost her a distinction grade being awarded for her dissertation.

Scenario 4 below, however, presents data from our most extreme case, in which miscommunication (or no communication at all) was apparent throughout the course of the supervision. It is unfortunate that Janet, the supervisee, was less able linguistically in our judgment than our other supervisees (as evidenced by our interactions with her during nearly 10 hours of interviews and our reading of around 23,000 words of her writing). Janet was 
therefore in particular need of help, but despite her repeated requests, received very little guidance from her supervisor.

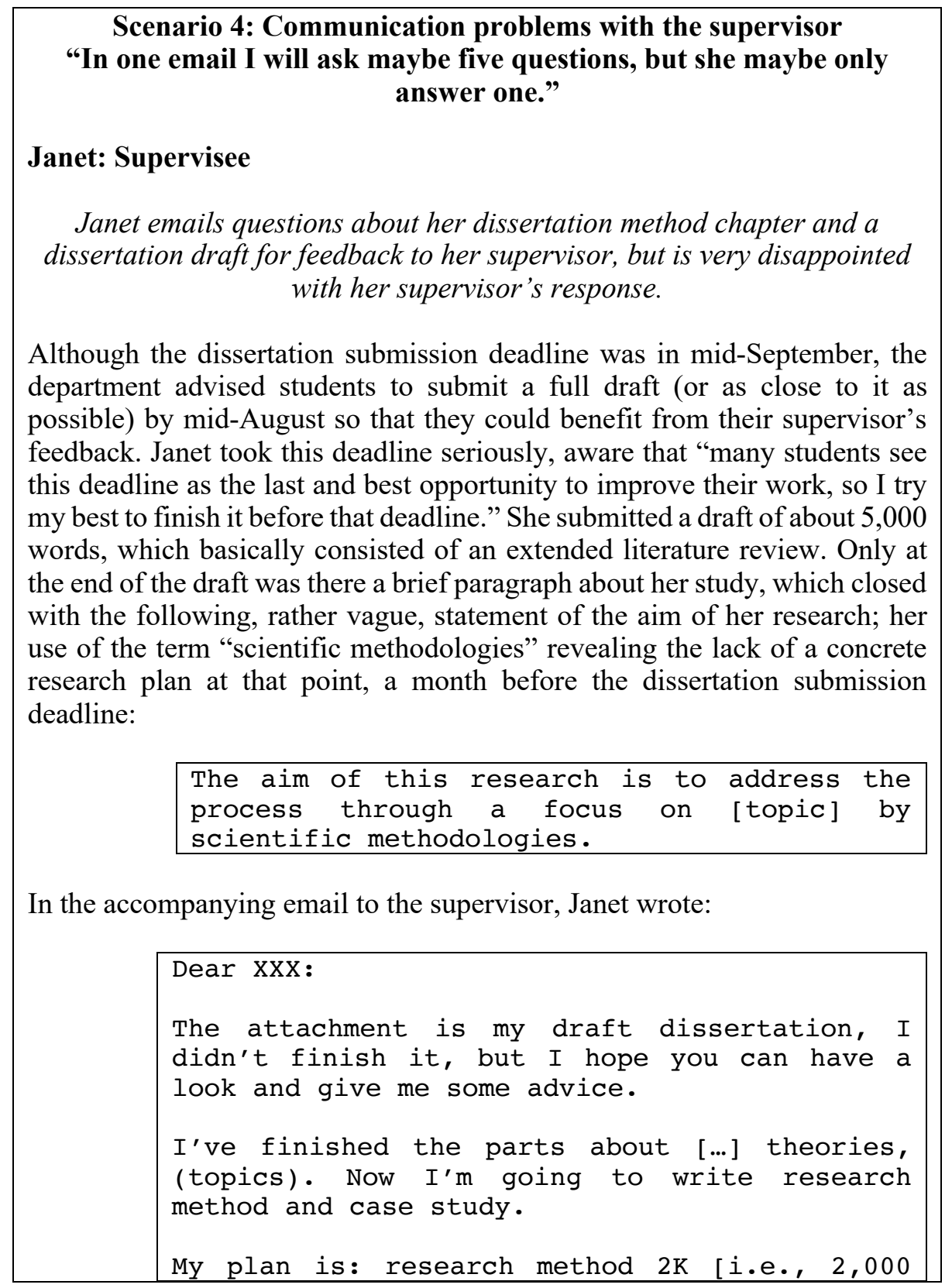




\begin{tabular}{|c|c|}
\hline & $\begin{array}{l}\text { words], case study } 3 \mathrm{~K} \text {, discussion and critical } \\
\text { opinion 3K, limitation and future direction } \\
500 \text {, conclusion 1K. That is } 15,000 \text { with } 5 \mathrm{k}+ \\
\text { I've finished. } \\
\text { And, I have some questions about research } \\
\text { method. I heard from other students said that } \\
\text { we should write it based on the [research } \\
\text { methods module], which means we have to write } \\
\text { something like ontology or interpretative } \\
\text { approach. But I read some journals, the } \\
\text { methodology chapters are often very short and } \\
\text { written by their own language and it is not } \\
\text { that theoretical. } \\
\text { How can I write about this? } \\
\text { Besides, about the research, I tend to do it } \\
\text { with combination of observation, interview and } \\
\text { survey, to prove the theory as well as find } \\
\text { something is not mentioned in theories. What } \\
\text { do you think about it? Does it mean I have to } \\
\text { use critical approach of methodology? [...]. } \\
\text { And at last, thanks for your time! BTw, do I } \\
\text { have a deadline of submitting the final draft? } \\
\text { Thank you! And I'll go for proof reading after } \\
\text { I finished the final draft, THx } \\
\text { Regards, } \\
\text { Janet }\end{array}$ \\
\hline $\begin{array}{l}\text { struggled } \\
\text { just over } \\
\text { evaluatio } \\
\text { create mo } \\
\text { actual stu } \\
\text { Janet's q } \\
\text { module, } \\
\text { "understa } \\
\text { it." Janet" } \\
\text { list of po } \\
\text { questions }\end{array}$ & $\begin{array}{l}\text { questions concerned research methodology, which she had } \\
\text { ractically no advice on up to this point, and which she had } \\
\text { vith. The supervisor responded the following day with an email of } \\
00 \text { words, offering, once again, little specific advice. The only } \\
\text { of Janet's 5,000-word draft was that it needed to be condensed to } \\
\text { e space for the remaining parts of the dissertation, i.e., for her } \\
\text { y, which, the supervisor wrote, should be the longest part. As for } \\
\text { estion about whether she should draw on the research methods } \\
\text { le responded that the methodology chapter should show her } \\
\text { ding of the material" from the module but didn't "need to follow } \\
\text { question about how to write about methodology received a brief } \\
\text { th the chapter should address, such as to explain the research } \\
\text { to describe how she collected and analyzed data, and what ethical }\end{array}$ \\
\hline
\end{tabular}


issues emerged. The supervisor didn't answer Janet's questions about the specific methods for her study, nor did she offer any comments on Janet's plan for the overall structure of her dissertation.

Talking about this email exchange in the interview, Janet didn't try to hide her anger:

And she didn't read it [Janet's dissertation draft] at all. And what she said is just you need work to do. Of course I know I need work to do. I know it, but I need the real advice about my work.

She complained that, as before, her questions and her needs were being ignored:

in one email I will ask maybe five questions, but she maybe only answer one....

What are the lessons to be taken from this episode?

What should/could Janet have done to solve this problem?

What could Janet's department do to prevent these kinds of situations from happening?

How could this episode be used by lecturers or support tutors to help students?

Workshop participants may well find it disturbing that only a month before the dissertation deadline Janet is so vague about the methodology of her study. Why was the design of her research not finalized long before? In fact, Janet had sent survey questions to her supervisor much earlier in the supervision but had received no feedback on them, and worked mostly alone in trying to figure out the best way forward. Like Jay, Janet had been required to take a research methods module to prepare her for her dissertation, but her knowledge of methods and methodologies appears worryingly nebulous, even by this advanced stage of her programme.

With such an obvious need for careful guidance and clear communication, workshop participants will likely debate how less independent students can and should be supervised, how far supervision should go, and how communication should be effected in cases such as these. Options could include regular face-to-face meetings and regular deadlines to produce short pieces of writing; despite Janet's repeatedly requesting face-to-face meetings, her supervisor (who did not respond to our request to participate in our study) never 
offered meetings to Janet, despite the fact that her department stipulated that face-to-face meetings should take place. Neither did Janet ever find her supervisor's brief comments on her work specific or clear enough to adequately guide her. Like the international student in Krase's (2007) study, Janet's case is characterized by a supervisory dyad at odds regarding what they expect and are prepared to offer; and poor communication only exacerbated this divide. We cannot tell why Janet's supervisor offered so little, or whether she sensed Janet's initial disappointment, which later turned to frustration and anger, at the manner in which she was supervised. Nonetheless, we believe that better, more regular communication could have enhanced Janet's experience.

\section{AN ADDITIONAL TEACHING AND LEARNING ACTIVITY}

We have provided four problem-solution scenarios that can be used by teaching and learning practitioners and support tutors as workshop activities with supervisors and supervisees on training and development programmes, alerting participants to common issues arising in supervisions and leading to discussion of supervisees' social networks, problems interpreting supervisors' feedback, expectations regarding different supervisory roles and styles, and problems of miscommunication. We have provided accompanying questions for reflection at the end of each scenario, although of course the questions could be rewritten depending on the context and audience (e.g., supervisees only, supervisors only, a mixed supervisee-supervisor audience, etc.). These activities could also be modified to address the needs of doctoral as opposed to master's supervisees and their supervisors. Indeed, in our experience of leading workshops for supervisors, issues relevant to both master's and doctoral supervision tend to be raised, with the discussion sometimes bringing to light the differences between the two - that is, why a particular course of action would be suitable as part of master's but not doctoral supervision and vice versa. While the constraints and affordances of doctoral supervisory contexts will differ, as we pointed out near the start of this paper, the literature is replete with narratives of doctoral students' difficulties that align with the themes uncovered in our master's study.

We close with a few words about an alternative activity to further promote discussion and reflection.

\section{The Undelivered Letter}

We argued earlier that we were keen to avoid giving the impression that the difficulties we have described are peculiar to international students; we can easily imagine home students facing the same issues and struggles. But given our focus on international students in this piece, it is appropriate to highlight that international students' previous educational experiences in their home 
countries and any previous experiences of supervision there may have been very different - as we saw in the case of Clara. This undelivered letter activity would provide a vehicle for supervisees to describe these previous assumptions, demystifying them for the support tutor, as explained below.

Support tutors who are approached by supervisees troubled or dissatisfied with current supervision arrangements may ask the student to write a letter to their supervisor detailing their frustration and its causes. The tutor would make clear to the student that this letter would not be delivered to the supervisor, but would be read by the support tutor in order to understand the supervisee's perspective and to then propose further action. (The fact the letter will not be delivered is designed to encourage frankness on the part of the supervisee.) For instance, the tutor may decide to mediate between student and supervisor and suggest to the supervisor how altered supervisory arrangements could better meet the student's expectations. Another possibility would be that the letter reveals to the tutor that the supervisee has what $\mathrm{s} / \mathrm{he}$ would regard as inappropriate expectations of supervision, and the tutor would then be able to clarify what the supervisee is entitled to expect, perhaps with the aid of departmental guidelines outlining the supervisory policy. Alternatively, the support tutor may have supervisees keep diaries for a period during their supervision, again charting their supervisory relationship and pinpointing the causes of dissatisfaction.

In conclusion, we believe our activities will help supervisees, supervisors, and teaching and learning instructors and support tutors to shed light on the occluded genre of supervision, which often takes the form of "an individualized and privatised affair" (Hockey, 1997, p. 65). We feel that awareness-raising activities such as these will likely prove beneficial to staff and students alike, and that our activities also have the advantage of being derived from grounded, empirical data rather than being artificial situations that may or may not ring true. We cannot claim they will lead discussants to discover neat solutions; but these scenarios can be defended as embodying some of the most common issues emerging from supervisory experiences as attested by empirical data, and as vehicles for talk and reflection to prepare discussants to enact their roles in a more informed manner.

\section{REFERENCES}

Acker, S., Hill, T., \& Black, E. (1994). Thesis supervision in the social sciences: Managed or negotiated? Higher Education, 28, 483-498. https://doi.org/10.1007/BF01383939

Aspland, T. (1999). "You learn round and I learn square": Mei's story. In Y. Ryan \& O. Zuber-Skerritt (Eds.), Supervising postgraduates from non- 
English speaking backgrounds (pp. 25-39). Buckingham, United Kingdom: SRHE and Open University Press.

Blakeslee, A. M. (1997). Activity, context, interaction, and authority: Learning to write scientific papers in situ. Journal of Business \& Technical Communication, 11 ,

125-169. https://doi.org/10.1177/1050651997011002001

Brown, G., \& Atkins, M. (1988). Effective teaching in higher education. London: Routledge.

Burns, R., Lamm, R., \& Lewis, R. (1999). Orientations to higher degree supervision: A study of supervisors and students in education. In A. Holbrook \& S. Johnston (Eds.), Supervision of postgraduate research in education (pp. 55-74). Coldstream, Victoria: Australian Association for Research in Education.

Delamont, S., Atkinson, P., \& Parry, O. (2000). The doctoral experience: Success and failure in graduate school. London: Falmer Press.

Duff, P. A. (2008). Case study research in applied linguistics. New York: Lawrence Erlbaum.

Dysthe, O. (2002). Professors as mediators of academic text cultures: An interview study with advisors and master's degree students in three disciplines in a Norwegian university. Written Communication, 19, 493544. https://doi.org/10.1177/074108802238010

Gatfield, T. (2005). An investigation into PhD supervisory management styles: Development of a dynamic conceptual model and its managerial implications. Journal of Higher Education Policy and Management, 27, 311-325. https://doi.org/10.1080/13600800500283585

Golde, C. (2010). Entering different worlds: Socialization into disciplinary communities. In S. K. Gardner \& P. Mendoza (Eds.), On becoming a scholar: Socialization and development in doctoral education (pp. 79 95). Sterling, VA: Stylus.

Grant, B., \& Graham, A. (1994). "Guidelines for discussion": A tool for managing postgraduate supervision. In O. Zuber-Skerritt \& Y. Ryan (Eds.), Quality in postgraduate education (pp. 165-177). London: Kogan Page.

Grant, B. M. (2008). Agonistic struggle: Master-slave dialogues in humanities supervision. Arts \& Humanities in Higher Education, 7, 9-27. https://doi.org/10.1177/1474022207084880

Grant, B. M. (2010a). Fighting for space in supervision: Fantasies, fairytales, fictions and fallacies. International Journal of Qualitative Studies in Education, 18(3),

337-354. https://doi.org/10.1080/09518390500082483 
Grant, B. M. (2010b). Improvising together: The play of dialogue in humanities supervision. Arts \& Humanities in Higher Education, 9, 271-288. https://doi.org/10.1177/1474022210379376

Green, B. (2005). Unfinished business: Subjectivity and supervision. Higher Education Research \& Development, 24, 151-163. https://doi.org/10.1080/07294360500062953

Guerin, C., Kerr, H., \& Green, I. (2015). Supervision pedagogies: Narratives from the field. Teaching in Higher Education, 20, 107-118. https://doi.org/10.1080/13562517.2014.957271

Halse, C. (2011). "Becoming a supervisor": The impact of doctoral supervision on supervisors' learning. Studies in Higher Education, 36, 557-570. https://doi.org/10.1080/03075079.2011.594593

Harwood, N., \& Petrić, B. (2017). Experiencing master's supervision: Perspectives of international students and their supervisors. Abingdon, United Kingdom: Routledge.

Hockey, J. (1994). Establishing boundaries: Problems and solutions in managing the $\mathrm{PhD}$ supervisor's role. Cambridge Journal of Education, 24, 293-305. https://doi.org/10.1080/0305764940240211

Hockey, J. (1996). Strategies and tactics in the supervision of UK social science $\mathrm{PhD}$ students. Qualitative Studies in Education, 9, 481-500. https://doi.org/10.1080/0951839960090409

Hockey, J. (1997). A complex craft: United Kingdom $\mathrm{PhD}$ supervision in the social sciences. Research in Post-Compulsory Education, 2, 45-70. https://doi.org/10.1080/13596749700200004

Hyland, F. (1998). The impact of teacher written feedback on individual writers. Journal of Second Language Writing, 7, 255-286. https://doi.org/10.1016/S1060-3743(98)90017-0

Hyland, F., \& Hyland, K. (2001). Sugaring the pill: Praise and criticism in written feedback. Journal of Second Language Writing, 10, 185-202. https://doi.org/10.1016/S1060-3743(01)00038-8

Kleijn, R. A. M., de Bronkhorst, L. H., Meijer, P. C., Pilot, A., \& Brekelmans, M. (2016). Understanding the up, back, and forward-component in master's thesis supervision with adaptivity. Studies in Higher Education, 41, 1463-1479. https://doi.org/10.1080/03075079.2014.980399

Kleijn, R. A. M., de Meijer, P. C., Brekelmans, M., \& Pilot, A. (2015). Adaptive research supervision: Exploring expert thesis supervisors' practical knowledge. Higher Education Research \& Development, 34, 117-130. https://doi.org/10.1080/07294360.2014.934331

Krase, E. (2007). "Maybe the communication between us was not enough": Inside a dysfunctional advisor/L2 advisee relationship. Journal of English for Academic Purposes, 6, 55-70. https://doi.org/10.1016/j.jeap.2006.12.001 
Kuwahara, N. (2008). It's not in the orientation manual: How a first-year doctoral student learned to survive in graduate school. In C. P. Casanave \& X. Li (Eds.), Learning the literacy practices of graduate school: Insiders' reflections on academic enculturation (pp. 186-200). Ann Arbor: University of Michigan Press.

Lee, A. (2008). How are doctoral students supervised? Concepts of doctoral research supervision. Studies in Higher Education, 33, 267-281. https://doi.org/10.1080/03075070802049202

Lee, A. (2012). Successful research supervision: Advising students doing research. Abingdon, United Kingdom: Routledge.

Liu, L., Weiser, I., Silva, T., Alsup, J., Selfe, C., \& Hawisher, G. (2008). It takes a community of scholars to raise one: Multiple mentors as key to my growth. In C. P. Casanave \& X. Li (Eds.), Learning the literacy practices of graduate school: Insiders' reflections on academic enculturation (pp. 166-183). Ann Arbor: University of Michigan Press.

Manathunga, C. (2014). Intercultural postgraduate supervision: Reimagining time, place and knowledge. Abingdon, United Kingdom: Routledge.

McAlpine, L., Paulson, J., Gonsalves, A., \& Jazvac-Martek, M. (2012). "Untold" doctoral stories: Can we move beyond cultural narratives of neglect? Higher Education Research \& Development, 31(4), 511-523. https://doi.org/10.1080/07294360.2011.559199

Organization for Economic Cooperation and Development. (2013). Education indicators in focus. Available at http://www.oecd.org/education/skillsbeyond-school/EDIF\%202013--N¹4\%20

Paltridge, B. (2004). The exegesis as a genre: an ethnographic investigation. In L. J. Ravelli \& R. A. Ellis (Eds.), Analysing academic writing: Contextualized frameworks (pp. 84-103). London: Continuum.

Salmon, P. (1992). Achieving a PhD-Ten students' experience. Stoke-onTrent: Trentham Books.

Schneider, M. L., \& Fujishima, N. K. (1995). When practice doesn't make perfect: The case of a graduate ESL student. In D. Belcher \& G. Braine (Eds.), Academic writing in a second language: Essays on research and pedagogy (pp. 3-22). Norwood, NJ: Ablex.

Seloni, L. (2012). Academic literacy socialization of first year doctoral students in US: A micro-ethnographic perspective. English for Specific Purposes, 31, 47-59. https://doi.org/10.1016/j.esp.2011.05.004

Starfield, S., \& Ravelli, L.J. (2006). "The writing of this thesis was a process that I could not explore with the positivistic detachment of the classical sociologist": Self and structure in New Humanities research theses. Journal of English for Academic Purposes, 5, 222-243. https://doi.org/10.1016/j.jeap.2006.07.004 
Taha, N., \& Cox, A. (2016). International students' networks: A case study in a UK university. Studies in Higher Education, 41, 182-198. https://doi.org/10.1080/03075079.2014.927851

Todd, M. J., Smith, K., \& Bannister, P. (2006). Supervising a social science undergraduate dissertation: Staff experiences and perceptions. Teaching in Higher Education, 11, 161-173. https://doi.org/10.1080/13562510500527693

Turner, G. (2015). Learning to supervise: Four journeys. Innovations in Education and Teaching International, 52, 86-98. https://doi.org/10.1080/14703297.2014.981840

UNESCO. (2016). Global flow of tertiary international students. Available at http://uis.unesco.org/en/uis-student-flow

Vehviläinen, S. (2009). Problems in the research problem: Critical feedback and resistance in academic supervision. Scandinavian Journal of Educational Research, 53, 185-201. https://doi.org/10.1080/00313830902757592

Vilkinas, T. (2005). The supervisor's role as manager of the PhD journey. In P. Green (Ed.), Supervising postgraduate research: Contexts and processes, theories and practices (pp. 163-177). Melbourne: RMIT University Press.

Zappa-Hollman, S. (2007). Academic literacy socialization of Mexican exchange students at a Canadian university (Unpublished $\mathrm{PhD}$ thesis). University of British Columbia.

Zappa-Hollman, S., \& Duff, P. A. (2015). Academic English socialization through individual networks of practice. TESOL Quarterly, 49, 333-368. https://doi.org/10.1002/tesq.188

NIGEL HARWOOD, $\mathrm{PhD}$, is a Reader in Applied Linguistics at the University of Sheffield, UK. His research interests include international students' experiences with academic writing, citation analysis, and TESOL textbooks and teaching materials. He has published in various international journals across the disciplines of applied linguistics and higher education, including Journal of Pragmatics, Journal of Second Language Writing, Written Communication, and Studies in Higher Education. He has edited volumes with CUP and Palgrave Macmillan, and is co-editor of the Elsevier journal English for Specific Purposes. Email: n.harwood@,sheffield.ac.uk

BOJANA PETRIĆ, PhD, is a senior lecturer in the Department of Applied Linguistics and Communication at Birkbeck, University of London. She has published in the area of academic writing, particularly source use and citing, in journals such as the Journal of Second Language Writing, Language Teaching, 
and Written Communication. She serves as the Deputy Chair of the European Association for the Teaching of Academic Writing and the Book Review Editor of the Journal of English for Academic Purposes. Email: b.petric@bbk.ac.uk

Manuscript submitted: June 28, 2018 Accepted for publication: September 18, 2018 